\title{
Task 6.3 - Engineering Performance of Advanced Structural Materials
}

\author{
Semi-Annual Report \\ January 1 - June 30, 1995
}

By

John P. Hurley

RECEIVED

John Kay

Jan W. Nowok

Allf 141997

Mark Schuster

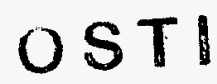

Work Performed Under Contract No.: DE-FC21-93MC30097

\author{
For \\ U.S. Department of Energy \\ Office of Fossil Energy \\ Morgantown Energy Technology Center \\ P.O. Box 880 \\ Morgantown, West Virginia 26507-0880
}

By

Energy and Environmental Research Center

University of North Dakota

P. O. Box 9018

Grand Forks, North Dakota 58202-9018

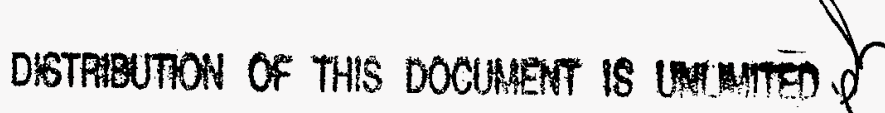

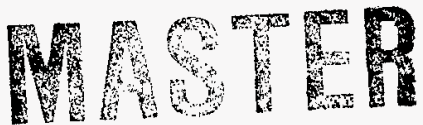




\section{Disclaimer}

This report was prepared as an account of work sponsored by an agency of the United States Government. Neither the United States Government nor any agency thereof, nor any of their employees, makes any warranty, express or implied, or assumes any legal liability or responsibility for the accuracy, completeness, or usefulness of any information, apparatus, product, or process disclosed, or represents that its use would not infringe privately owned rights. Reference herein to any specific commercial product, process, or service by trade name, trademark, manufacturer, or otherwise does not necessarily constitute or imply its endorsement, recommendation, or favoring by the United States Government or any agency thereof. The views and opinions of authors expressed herein do not necessarily state or reflect those of the United States Government or any agency thereof. 


\section{DISCLAIMER}

This report was prepared as an account of work sponsored by an agency of the United States Government. Neither the United States Government, nor any agency thereof, nor any of their employees makes any warranty, express or implied, or assumes any legal liability or responsibility for the accuracy, completeness, or usefulness of any information, apparatus, product, or process disclosed or represents that its use would not infringe privately owned rights. Reference herein to any specific commercial product, process, or service by trade name, trademark, manufacturer, or otherwise does not necessarily constitute or imply its endorsement, recommendation, or favoring by the United States Government or any agency thereof. The views and opinions of authors expressed herein do not necessarily state or reflect those of the United States Government or any agency thereof.

\section{ACKNOWLEDGMENT}

This report was prepared with the support of the U.S. Department of Energy (DOE), Morgantown Energy Technology Center, Cooperative Agreement No. DE-FC21-93MC30097. However, any opinions, findings, conclusions, or recommendations expressed herein are those of the author(s) and do not necessarily reflect the views of the DOE.

\section{EERC DISCLAIMER}

LEGAL NOTICE This research report was prepared by the Energy \& Environmental Research Center (EERC), an agency of the University of North Dakota, as an account of work sponsored by U.S. Department of Energy. Because of the research nature of the work performed, neither the EERC nor any of its employees makes any warranty, express or implied, or assumes any legal liability or responsibility for the accuracy, completeness, or usefulness of any information, apparatus, product, or process disclosed, or represents that its use would not infringe privately owned rights. Reference herein to any specific commercial product, process, or service by trade, trademark, manufacturer, or otherwise does not necessarily constitute or imply its endorsement or recommendation by the EERC. 


\section{TABLE OF CONTENTS}

LIST OF FIGURES $\ldots \ldots \ldots \ldots \ldots \ldots \ldots \ldots \ldots \ldots \ldots$ ii

LIST OF TABLES $\ldots \ldots \ldots \ldots \ldots \ldots \ldots \ldots \ldots \ldots \ldots \ldots \ldots \ldots \ldots \ldots \ldots \ldots$

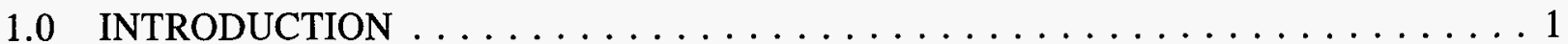

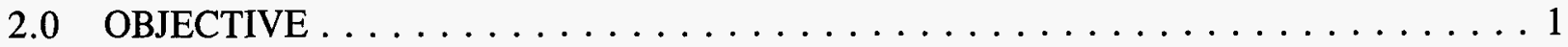

3.0 ACCOMPLISHMENTS $\ldots \ldots \ldots \ldots \ldots \ldots \ldots \ldots \ldots \ldots \ldots \ldots \ldots \ldots$

3.1 Silicon Carbide Joining $\ldots \ldots \ldots \ldots \ldots \ldots \ldots \ldots \ldots \ldots \ldots \ldots \ldots \ldots \ldots$

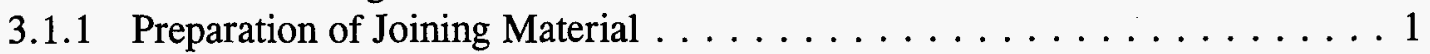

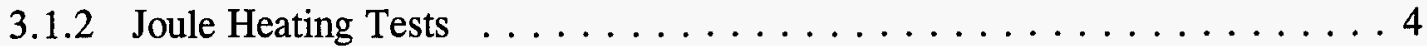

3.2 Silicon Nitride Joining $\ldots \ldots \ldots \ldots \ldots \ldots \ldots \ldots \ldots \ldots \ldots \ldots \ldots \ldots \ldots \ldots$ 


\section{LIST OF FIGURES}

1 SEM micrograph of the initial $50 / 50$ formulation pellet showing large particles composed

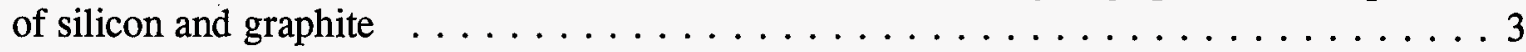

2 SEM micrograph of the 50/50 formulation-after-sieving pellet, showing improved particle

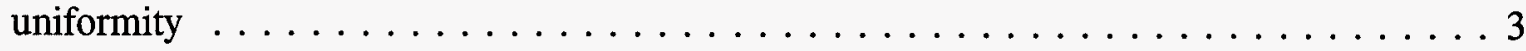

3 Schematics of jig used to hold test bars together $\ldots \ldots \ldots \ldots \ldots \ldots \ldots \ldots$

\section{LIST OF TABLES}

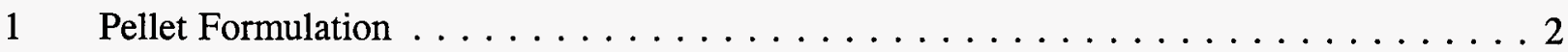

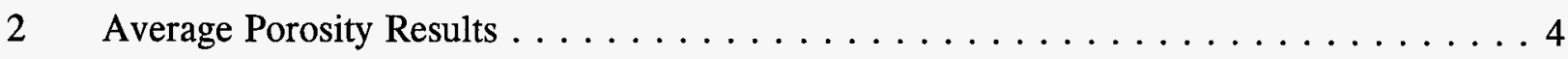




\section{TASK 6.3 - ENGINEERING PERFORMANCE OF ADVANCED STRUCTURAL MATERIALS}

\subsection{INTRODUCTION}

Future energy systems operating at higher temperatures and pressures than current coal-fired boilers require improved materials to achieve high performance and long life. These energy systems will be required to fire low-grade fuels and to meet higher energy conversion efficiencies. The steam cycle used at present is limited to a maximum temperature of $550^{\circ} \mathrm{C}$, because above that the stainless steel tubes deform and corrode excessively. To boost efficiency significantly, much higher working fluid temperatures are required. Although high-temperature alloys will suffice for the construction of these components in the near term, the greatest efficiency increases can only be reached with the use of advanced structural ceramics.

Advanced ceramics such as silicon carbide ( $\mathrm{SiC}$ ) are resistant to corrosion and are very strong at much higher temperatures than today's metals. For example, SiC sublimes without melting at temperatures over $2000^{\circ} \mathrm{C}$. This makes $\mathrm{SiC}$ difficult to use in the fabrication of large structures, because pieces made from $\mathrm{SiC}$ cannot be joined together in the same way that metals can be welded. Therefore, the size of the monolithic ceramic structures that can be manufactured are limited by the size of the sintering furnaces (approximately 10 feet for sintered alpha silicon carbide). In order to make larger objects such as heat exchangers, many small ceramic pieces must be fused or joined. In addition, repair of the objects will require the use of field joining techniques. At present, no joining techniques for high-temperature structural ceramics are routinely available.

\subsection{OBJECTIVE}

The objective of this work at the Energy \& Environmental Research Center (EERC) is to develop a patentable technique for joining large silicon-based advanced ceramics in the field. The key to developing a successful technique will be the use of reactive joining compounds to lower the joining temperature but without leaving continuous channels of unreacted compounds that can weaken the joint or be conduits for corrosion at temperatures over $1400^{\circ} \mathrm{C}$. Special efforts will be made in this project to transfer the developed technologies to the materials industry via licensing agreements through the EERC Foundation.

\subsection{ACCOMPLISHMENTS}

\subsection{Silicon Carbide Joining}

\subsubsection{Preparation of Joining Material}

Pellet materials were prepared by combining silicon carbide, graphite, and silicon powders with a solvent, binder, and plasticizer in three formulations as shown in Table 1. Two size ranges of $\mathrm{SiC}$ were used to increase the packing efficiency of the material. The materials were mixed in a 


\section{TABLE 1}

Pellet Formulation

\begin{tabular}{|c|c|c|c|c|c|c|c|}
\hline \multirow[t]{2}{*}{ Material } & \multirow[t]{2}{*}{ Type } & \multicolumn{2}{|c|}{$\begin{array}{c}50 \% \mathrm{SiC} \\
50 \% \mathrm{Si}+\mathrm{C} \\
\end{array}$} & \multicolumn{2}{|c|}{$\begin{array}{c}75 \% \mathrm{SiC} \\
25 \% \mathrm{Si}+\mathrm{C} \\
\end{array}$} & \multicolumn{2}{|c|}{$\begin{array}{c}90 \% \mathrm{SiC} \\
10 \% \mathrm{Si}+\mathrm{C}\end{array}$} \\
\hline & & amount & $\mathrm{wt} \%$ & amount & $\mathrm{wt} \%$ & amount & wt\% \\
\hline $\mathrm{SiC}$ & $\begin{array}{l}9000 \text {-grit } \mathrm{SiC} \text { powder, Norton Industrial } \\
\text { Ceramics, Worcester, MA }\end{array}$ & $0.88 \mathrm{~g}$ & 11.8 & $1.32 \mathrm{~g}$ & 17.6 & $1.58 \mathrm{~g}$ & 21.1 \\
\hline $\mathrm{SiC}$ & $\begin{array}{l}\text { 1200-grit SIKA III SiC powder, } \\
\text { Washington Mills, Niagara Falls, NY }\end{array}$ & $2.64 \mathrm{~g}$ & 35.3 & $3.96 \mathrm{~g}$ & 52.9 & $4.76 \mathrm{~g}$ & 63.6 \\
\hline Silicon & $\begin{array}{l}1 \text { to } 5 \text { micron, Aldrich Chemical, } \\
\text { Milwaukee, WI }\end{array}$ & $2.47 \mathrm{~g}$ & 33.0 & $1.24 \mathrm{~g}$ & 16.6 & $0.49 \mathrm{~g}$ & 6.6 \\
\hline Graphite & 1 to 2 micron, Alfa Aesar, Ward Hill, MA & $1.05 \mathrm{~g}$ & 14.0 & $0.53 \mathrm{~g}$ & 7.1 & $0.21 \mathrm{~g}$ & 2.8 \\
\hline $\begin{array}{l}\text { Solvent/ } \\
\text { Lubricant }\end{array}$ & Acetone, Fisher Scientific, Fair Lawn, NJ & $6.0 \mathrm{~mL}$ & --- & $6.0 \mathrm{~mL}$ & $-\cdots$ & $6.0 \mathrm{~mL}$ & --- \\
\hline Binder & $\begin{array}{l}\text { Collodion USP, Fisher Scientific, Fair } \\
\text { Lawn, NJ }\end{array}$ & $4.0 \mathrm{~mL}$ & 2.1 & $4.0 \mathrm{~mL}$ & 2.1 & $4.0 \mathrm{~mL}$ & 2.1 \\
\hline Plasticizer & $\begin{array}{l}\text { Ethylene glycol, Fisher Scientific, Fair } \\
\text { Lawn, NJ }\end{array}$ & $0.25 \mathrm{~mL}$ & 3.7 & $0.25 \mathrm{~mL}$ & 3.7 & $0.25 \mathrm{~mL}$ & 3.7 \\
\hline
\end{tabular}

mortar with a pestle for 15 minutes and allowed to dry. After drying, the mixture was broken up into a uniform powder.

Approximately 0.85 grams of the mixture was moistened with 15 to 20 drops of acetone (enough to moisten the mixture but not saturate). The sample was then pressed in a $31-\mathrm{mm}$ diameter cylindrical uniaxial die, under vacuum, in a manually operated 30-ton hydraulic press (Spex Industries, Edison, New Jersey) for 10 minutes at $220 \mathrm{MPa}$ (32000 psi). The sample was then removed and allowed to dry. This procedure produces a pellet with a thickness of $0.5 \mathrm{~mm}$. Pellets were sectioned and polished for scanning electron microscopic (SEM) examination to determine the homogeneity of the pellets and their porosities.

A SEM micrograph of the initial 50/50 formulation pellet is shown in Figure 1. Particles larger than 20 microns can be clearly seen. The large silicon and graphite particles could give rise to large pore spaces or may not react completely during the joining process, which is not desirable. Equally large particles were observed in the $75 / 25$ and $90 / 10$ formulations. Sieving of the powders in an Allen-Bradley sonic sifter (Fisher Scientific, Fair Lawn, New Jersey) to less than 10 microns was employed in later formulations. A SEM micrograph of the 50/50 formulation pellet made after sieving is shown in Figure 2. Particle uniformity is much improved. The pellet porosity shows improvement as well. The porosities of the pellets before and after sieving are shown in Table 2. Estimations of porosity were performed on the SEM using a grey-level histogram of five different areas of each sample. 


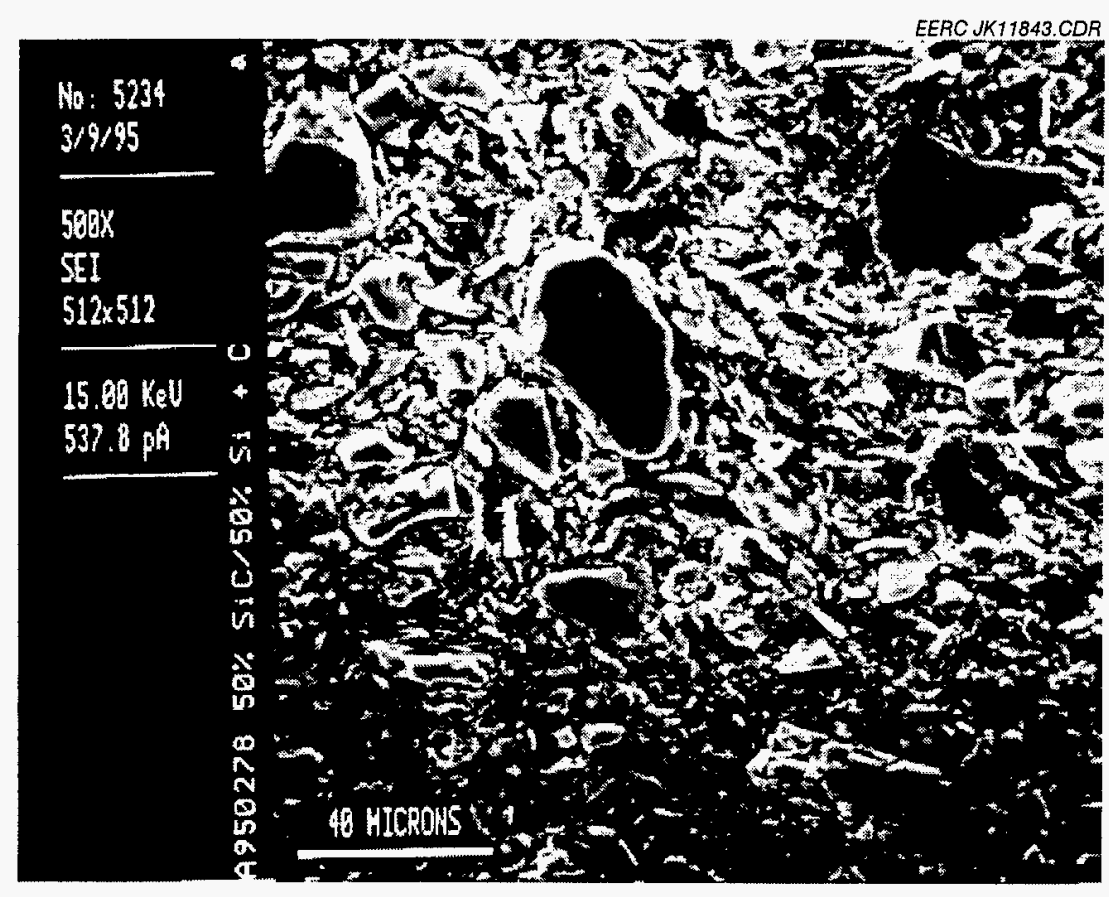

Figure 1. SEM micrograph of the initial 50/50 formulation pellet showing large particles composed of silicon and graphite.

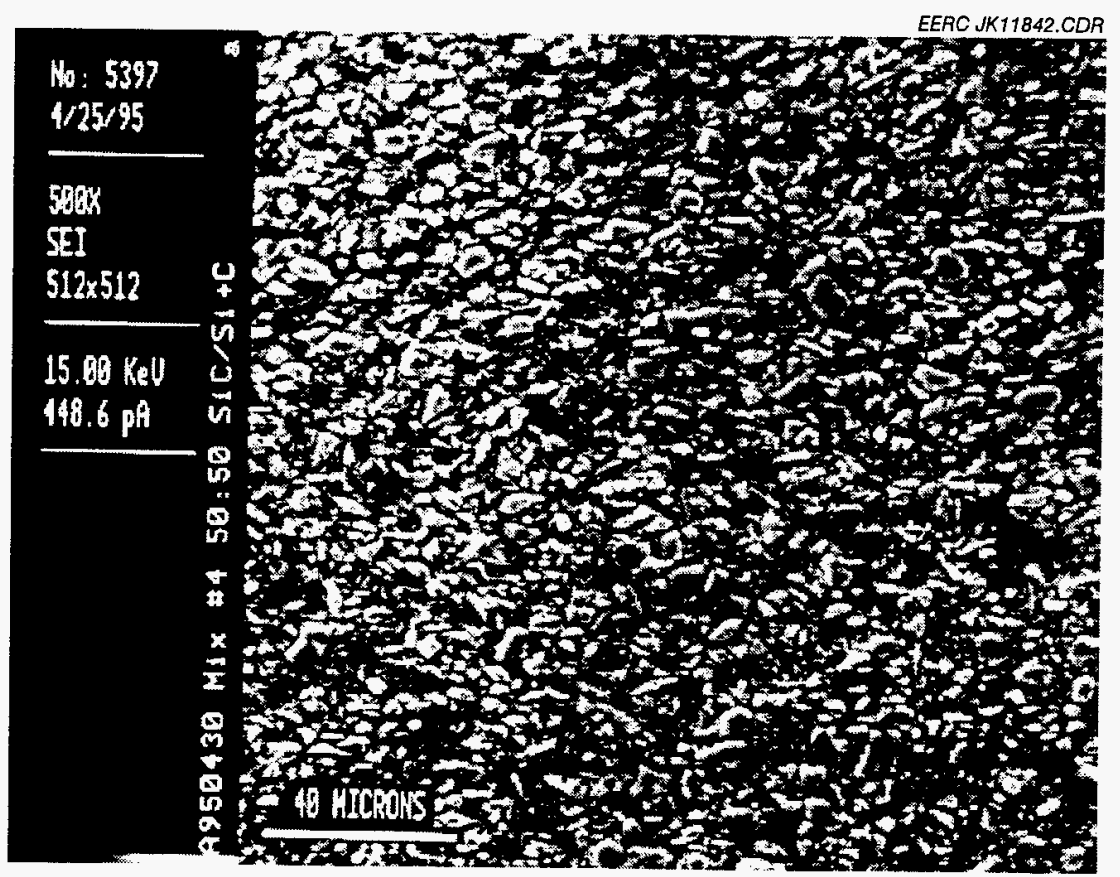

Figure 2. SEM micrograph of the 50/50 formulation-after-sieving pellet, showing improved particle uniformity. 
TABLE 2

Average Porosity Results

\begin{tabular}{ccc}
\hline Formulation & $\begin{array}{c}\text { Initial Pellet } \\
\text { Porosity, \% }\end{array}$ & $\begin{array}{c}\text { After-Sieving Pellet } \\
\text { Porosity, \% }\end{array}$ \\
\hline $50 \% \mathrm{SiC} / 50 \% \mathrm{Si}+\mathrm{C}$ & 16.9 & 13.9 \\
$75 \% \mathrm{SiC} / 25 \% \mathrm{Si}+\mathrm{C}$ & 22.8 & 19.4 \\
$90 \% \mathrm{SiC} / 10 \% \mathrm{Si}+\mathrm{C}$ & 21.4 & 11.3 \\
\hline
\end{tabular}

\subsubsection{Joule Heating Tests}

No matter what compounds are used in joining $\mathrm{SiC}$, heat must be applied to the joint. Most often the heat comes from a secondary external source such as a furnace. Sometimes inductive heating or microwave heating is used. In each case, the object needs to be surrounded by the heater. This is not a problem for smaller objects or those that are at least small in two dimensions, such as a pipe. However, for objects that are large in two dimensions, such as heat exchanger panels, these heating methods are not applicable. Instead, it may be possible to connect electrodes to either side of a $\mathrm{SiC}$ joint and pass electric current through the material to cause resistive or Joule heating. With proper attachment of the electrodes, and because of the high thermal conductivity of $\mathrm{SiC}$, heating of the joint could be made very uniform. The method has an additional advantage in that the joint is placed in an electrical field that is known to reduce the temperature necessary for reaction between ceramic precursors, a technique known as combustion synthesis. This is an especially valuable attribute in cases where the joining is accomplished by reaction sintering.

Preliminary work showed that it was possible to heat $\mathrm{SiC}$ by passing an electric current through it. However, when using a constant-voltage power source such as a Variac for control, current runaway occurred as the $\mathrm{SiC}$ was heated. This happened because for a fixed voltage, the resistance drops as the temperature is raised which, in turn, causes the current to increase. However, as the current increases, the temperature increases further which drops the resistance, causing a further current and temperature rise. This leads to extremely rapid temperature escalations (approximately $300^{\circ}$ to $500^{\circ} \mathrm{C} /$ second) causing thermal shock and breakage of the bars. Therefore, a current limiting circuit needed to be constructed for the power source.

During this reporting period, a 208-volt power supply with a current limiting controller was constructed and used in the Joule heating of SiC. Hexoloy SA SiC tubing 0.375-inch OD, 0.25inch ID, and 2 inches in length has been heated to temperatures exceeding $1250^{\circ} \mathrm{C}$ for extended periods. Hexoloy test bars $(6 \times 8 \times 50 \mathrm{~mm})$ have also been heated to these temperatures. The specimens are held between two graphite electrodes in a jig as depicted in Figure 3. 


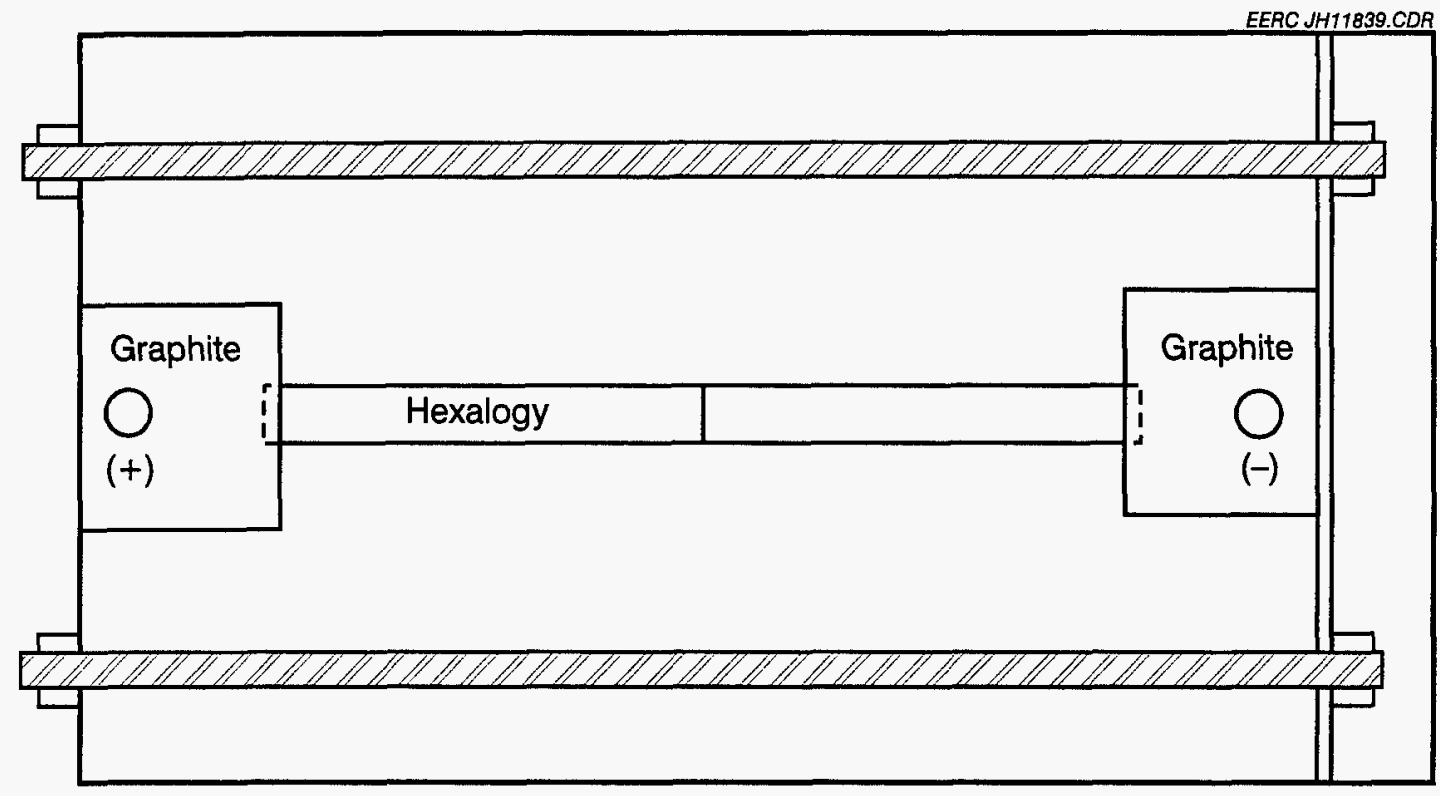

Figure 3. Schematics of jig used to hold test bars together.

To reduce surface resistance, a paste of vitreous carbon and water is painted on the surfaces of the specimen and allowed to dry. At low temperatures, the vitreous carbon conducts the electricity and heats the rod. It also insulates the electrodes and the thermocouple from the SiC to prevent them from reacting at high temperatures. A nitrogen gas stream is introduced to prevent the paste from oxidizing and to allow the use of a C-type (W-Re) thermocouple. When the voltage is applied, the temperature of the specimen slowly rises until about $300^{\circ} \mathrm{C}$ and then increases faster as the electrical resistance of the Hexoloy drops rapidly with increasing temperature. However, attempts to heat two samples end to end with this method and this power supply have not been successful. Contact resistance between the bars seems to be the reason.

\subsection{Silicon Nitride Joining}

During this reporting period, reaction sintering of SiAlON precursors was investigated in order to develop a pressureless joining material for $\mathrm{Si}_{3} \mathrm{~N}_{4}$ bars. We have focused on four major joining components: 1) SiAlON, 2) SiAlON with small amount of $\mathrm{Y}_{2} \mathrm{O}_{3}(6-8 \mathrm{wt} \%)$, 3) SiAlON formed during nitriding of polycarbosilane, and 4) partial oxidation of aluminum nitride and sintering with silicon in the presence of nitrogen. The latter technology is our novel concept.

To test the sinterability of the materials, they were compacted and heated at $1550^{\circ} \mathrm{C}$ for 5 hours in $\mathrm{N}_{2}$ atmosphere and annealed at the crystallization temperature of $1100^{\circ} \mathrm{C}$ for 1 hour. It was found that $\mathrm{Y}_{2} \mathrm{O}_{3}$ additive can strengthen the sintered material through elongation of silicon nitride grains and crystallization involving an intermediate-phase formation related to nitrogen-wollastonite. The nonuniform distribution of yttria causes the formation of areas enriched in SiAlON-Y phase. A preliminary assessment of sintering tests indicates the oxygen content in the nitrogen gas is an important factor affecting the reproducibility of the mechanical properties of the sintered material. 
According to French and Italian research data the SiAlON produced from commercial polycarbonsilane (Dow Corning X9-6348) and aluminum sec-butoxide modified with ethylacetone often has a high surface area and low sintering temperature. The polycarbosilane reduces the sintering temperature to about $1500^{\circ} \mathrm{C}$ as a result of fine particle formation during the process of nitriding the polycarbosilane. However, polycarbosilane has not been distributed in the U.S. market by Dow Corning since 1994. We have begun looking for a new vendor since the production of polycarbosilane in our laboratory is not possible because it requires a high pressure. 
M97002255

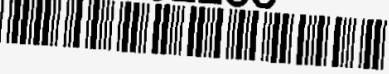

Report Number (14) DOE/MC/30097-- 5608

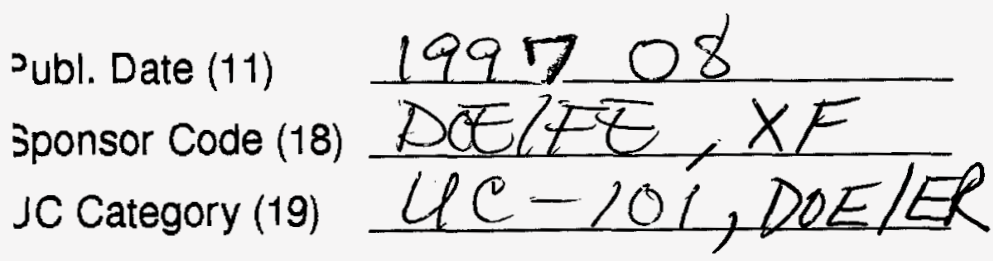

DOE 